\title{
The immune system in sporadic inclusion body myositis patients is not compromised by blood-flow restricted exercise training
}

Kasper Yde Jensen 1,3,6+, Mikkel Jacobsen ${ }^{1,2,3 \dagger}{ }^{1}$, Henrik Daa Schrøder ${ }^{3,4}$, Per Aagaard ${ }^{1}$, Jakob Lindberg Nielsen ${ }^{1}$, Anders Nørkær Jørgensen ${ }^{1,4}$, Eleanor Boyle ${ }^{7}$, Rune Dueholm Bech", Sofie Rosmark², Louise Pyndt Diederichsen ${ }^{2,6^{*}+}$ and Ulrik Frandsen ${ }^{1{ }^{\wedge}}$ (i)

\begin{abstract}
Background: Sporadic inclusion body myositis (SIBM) is clinically characterised by progressive proximal and distal muscle weakness and impaired physical function while skeletal muscle tissue displays abnormal cellular infiltration of T cells, macrophages, and dendritic cells. Only limited knowledge exists about the effects of low-load blood flow restriction exercise in sIBM patients, and its effect on the immunological responses at the myocellular level remains unknown. The present study is the first to investigate the longitudinal effects of low-load blood flow restriction exercise on innate and adaptive immune markers in skeletal muscle from sIBM patients.
\end{abstract}

Methods: Twenty-two biopsy-validated sIBM patients were randomised into either 12 weeks of low-load blood flow restriction exercise (BFRE) or no exercise (CON). Five patients from the control group completed 12 weeks of BFRE immediately following participation in the 12-week control period leading to an intervention group of 16 patients. Muscle biopsies were obtained from either the $\mathrm{m}$. tibialis anterior or the $\mathrm{m}$. vastus lateralis for evaluation of CD3-, CD8-, CD68-, CD206-, CD244- and FOXP3-positive cells by three-colour immunofluorescence microscopy and Visiopharm-based image analysis quantification. A linear mixed model was used for the statistical analysis.

Results: Myocellular infiltration of $\mathrm{CD}^{-} / \mathrm{CD}^{+}$expressing natural killer cells increased following BFRE $(P<0.05)$ with no changes in CON. No changes were observed for $\mathrm{CD}^{+} / \mathrm{CD}^{-}$or $\mathrm{CD}^{+} / \mathrm{CD}^{+} T$ cells in BFRE or $\mathrm{CON} . \mathrm{CD}^{+} /$ CD244 ${ }^{+}$T cells decreased in CON, while no changes were observed in BFRE. Pronounced infiltration of M1 proinflammatory $\left(\mathrm{CD} 8^{+} / \mathrm{CD}^{2} 26^{-}\right)$and $\mathrm{M} 2$ anti-inflammatory $\left(\mathrm{CD}^{+} 8^{+} / \mathrm{CD}^{206}{ }^{+}\right)$macrophages were observed at baseline; however, no longitudinal changes in macrophage content were observed for both groups.

Conclusions: Low-load blood flow restriction exercise elicited an upregulation in $\mathrm{CD}^{-} / \mathrm{CD}^{+}$expressing natural killer cell content, which suggests that 12 weeks of BFRE training evokes an amplified immune response in sIBM muscle. However, the observation of no changes in macrophage or T cell infiltration in the BFRE-trained patients indicates that patients with sIBM may engage in this type of exercise with no risk of intensified inflammatory activity.

Keywords: Sporadic inclusion body myositis, Inflammation, T lymphocytes, T cells, Macrophages, Disease progression, Blood flow restriction exercise

\footnotetext{
* Correspondence: louise.diederichsen@regionh.dk

Kasper Yde Jensen and Mikkel Jacobsen shared first authorship.

Louise Pyndt Diederichsen and Ulrik Frandsen shared last authorship.

${ }^{2}$ Department of Rheumatology, Odense University Hospital, Odense,

Denmark

${ }^{6}$ Center for Rheumatology and Spine Diseases, Copenhagen University

Hospital, Rigshospitalet, Copenhagen, Denmark

Full list of author information is available at the end of the article
}

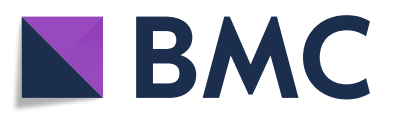

(c) The Author(s). 2019 Open Access This article is distributed under the terms of the Creative Commons Attribution 4.0 International License (http://creativecommons.org/licenses/by/4.0/), which permits unrestricted use, distribution, and reproduction in any medium, provided you give appropriate credit to the original author(s) and the source, provide a link to the Creative Commons license, and indicate if changes were made. The Creative Commons Public Domain Dedication waiver (http://creativecommons.org/publicdomain/zero/1.0/) applies to the data made available in this article, unless otherwise stated. 


\section{Introduction/background}

Sporadic inclusion body myositis (sIBM) is an acquired slowly progressing inflammatory myopathy with a late age onset (61-68 years of age) [1]. SIBM is characterised clinically by muscle weakness and atrophy, prominently observed in the quadriceps muscles and in the wrists and fingers $[2,3]$. In histological terms, sIBM involves inflammatory infiltrates, muscle fibre damage and cytoplasmatic fibrillary inclusions. Over time, the affected muscles accumulate degenerative changes that are dominated by fatty infiltration and muscle atrophy $[4,5]$. In result, patients experience a marked progressive decline in muscle strength and physical function. It has been reported that the annual decline in muscle strength averages between 5 and $16 \%$ per year $[6,7]$. This corresponds to a 5 to 10 -fold faster decline than in healthy adults of comparable age $[8,9]$. Unlike other subgroups of idiopathic inflammatory myopathies (IIMs), most sIBM patients are non-responsive to immunosuppressive medication [10].

Exercise-based interventions have been documented to induce skeletal muscle hypertrophy, increase contractile strength and to negate/attenuate inflammation in IIMs [11-14]. Therefore, clinical recommendations concerning physical activity in IIMs have gradually changed from avoiding exercise and limiting physical activity, to conversely encourage IIM patients to engage in exercise participation.

Exercises combining low-load muscle contractions and partial venous blood-flow restriction (blood-flow restricted exercise, BFRE) may be particularly relevant to individuals with profound muscle weakness, such as sIBM patients because of its potential ability to stimulate skeletal muscle growth and its potential antiinflammatory properties [15-17]. Previous case studies and case series have successfully implemented BFRE in sIBM, polymyositis (PM) and dermatomyositis (DM) patients [18-20].

Using a randomised controlled study design, we were unable to verify a direct performance enhancing impact of BFRE intervention in a group of frail sIBM patients [21]. However, when compared to care-as-usual sIBM patients $(\mathrm{CON})$, BFRE training appeared effective of reducing the rate of decline in lower limb muscle strength for this patient group [21].

To further understand the underlying pathophysiological mechanisms of the effects of BFRE in sIBM patients, this study investigated the adaptive and innate immune response of the affected muscles elicited during the 12 weeks of low-load BFRE training.

$\mathrm{T}$ cells are an important part of the adaptive immune system, particularly in relation to sIBM with various subgroups being of high relevance. Specifically, CD28 null $\mathrm{T}$ cells have been shown to be proinflammatory and cytotoxic in nature and to increase in density in patients with sIBM compared to agematched controls [22-26].

Tissue tolerance towards $\mathrm{T}$ cell immune infiltration is modulated by regulatory $\mathrm{T}$ cells $\left(\mathrm{T}_{\text {reg }}\right)$ residing locally within the skeletal muscle tissue. $\mathrm{T}_{\text {reg }}$ cells maintain immunological protection against self-antigens via inhibition of $\mathrm{T}$ cell activation and weakening of $\mathrm{T}$ cell effector function $[27,28]$. Specifically, in IIM patients, $\mathrm{T}_{\text {reg }}$ $\left(\mathrm{FOXP3}^{+}\right)$cells serve to counterbalance muscle destruction caused by cytotoxic $\left(\mathrm{CD}^{+}\right) \mathrm{T}$ cells [29]. Furthermore, $\mathrm{T}_{\text {reg }}$ cells are known to coordinate immune cell interactions involved in skeletal muscle growth and regeneration [30, 31], by regulating the transition from M1-biased to M2-biased macrophage phenotypes [32]. The reduced expression of $\mathrm{T}_{\text {reg }}$ cells observed in sIBM patients [29, 33] combined with high numbers of CD28 ${ }^{\text {null }} \mathrm{T}$ cells may facilitate autoimmune-like responses in sIBM muscle tissue [24].

Previous reports have shown that macrophages play a significant role in the recovery from muscle damage and repair while further facilitating myofibre growth [32, 34, 35]. Further, in healthy young adults, we recently observed that BFRE training can induce an upregulation in both pro- (M1) and anti-inflammatory (M2) macrophage content [16]. Natural killer (NK) cells represent a similarly important element of the innate immune system. Specifically, NK cells may be considered the innate immune system's counterpart to cytotoxic $\mathrm{CD}^{+} \mathrm{T}$ cells in the adaptive immune system and are known to increase in response to both acute and chronic exercise [36, 37].

The aim of the present study was to investigate the effects of longitudinal BFRE training on the expression of key immune cell populations involved in SIBM disease progression, skeletal muscle growth and regeneration. It was hypothesised that BFRE training would decrease the expression of cytotoxic $\mathrm{T}$ cell infiltrates, increase $\mathrm{T}_{\text {reg }}$ infiltrates and enhance $\mathrm{M} 1$ - to M2-biased macrophage transition in trained muscles. In turn, this would contribute to previously explained observations of retained muscle function following BFRE training in sIBM [21].

\section{Material and methods}

\section{Study design and experimental procedures}

The study was a randomised controlled trial (RCT). Recruited patients were randomly allocated to the intervention group (BFRE) or the control group $(\mathrm{CON})$, by using a $1: 1$ random allocation ratio design. Recruitment procedures, testing and training of patients have been described in detail elsewhere [38]. In brief, a total of 22 biopsy-validated [3] sIBM patients (Table 1) were recruited (for detailed overview of study design, see Fig. 1). 
Table 1 Baseline characteristics of included patients. BMI body mass index, MMT8 manual muscle testing 8

\begin{tabular}{|c|c|c|c|c|c|c|c|c|}
\hline & Age & Gender & BMI & Months from diagnosis & Creatine kinase & Health assessment questionnaire & МMT8 & Immunosuppressive medicine \\
\hline \multicolumn{9}{|c|}{$\operatorname{BFRE}(n=11)$} \\
\hline Mean & 67.5 & W/M: 3/8 & 24.71 & 57.8 & 549 & 0.85 & 69.6 & $4 / 11$ \\
\hline SD & 6.5 & & 3.19 & 87.7 & 397 & 0.83 & 6.2 & \\
\hline \multicolumn{9}{|c|}{ Control $(n=10)$} \\
\hline Mean & 69.2 & W/M: 2/8 & 24.69 & 46.6 & 308 & 1.125 & 67.9 & $2 / 10$ \\
\hline SD & 4.6 & & 4.68 & 27.2 & 247 & 0.88 & 6.0 & \\
\hline
\end{tabular}

\section{BFRE protocol}

The BFRE training protocol has been described in detail elsewhere [38]. In brief, the exercise protocol consisted of low-load $(\sim 25 \mathrm{RM})$ blood-flow occluded resistance training performed two times per week for 12 weeks, involving five different lower extremity exercises (three to four sets of each exercise).

Vascular occlusion of the lower limb was controlled by an inflatable pneumatic cuff (100-mm width) placed proximally at the thigh or calf. The cuff was connected to a computerised tourniquet system (Zimmer ATS 750, Zimmer, Inc., Warsaw, USA) that automatically regulated the cuff pressure $(110 \mathrm{mmHg})$ [39].

\section{Muscle biopsy sampling}

Muscle biopsies were obtained from $\mathrm{m}$. tibialis anterior or $\mathrm{m}$. vastus lateralis during local anaesthesia, and sterile conditions provided by an experienced medical doctor using a Bergström needle. The muscle samples immediately were embedded in Tissue Tek (4583, Sakura Finetek, Alphen aan den Rijn, The Netherlands) and frozen in nitrogen-cooled 2-methylbutane.

\section{Immunofluorescence}

Transverse serial sections $(8 \mu \mathrm{m})$ of the embedded muscle biopsies were cut in a cryostat at $-22{ }^{\circ} \mathrm{C}$ (HM 560 Cryo-Star Cryostat, Microm, Walldorf, Germany) and placed on SuperFrost plus glass slides (Thermo Fisher, Rockford, USA). The biopsy cryosections were fixed in $4 \%$ formaldehyde fixation solution containing $100 \mu \mathrm{L}$ of Triton X-100 (10\%) (Sigma-Aldrich, St. Louis, MO, USA), $200 \mu \mathrm{L}$ of formaldehyde (37\%) and $1.7 \mathrm{~mL}$ phosphate-buffered saline (PBS, × 10) (70013, Invitrogen, Paisley, UK) for $10 \mathrm{~min}$. Sections were rinsed for three cycles of 3 min followed by Protein Block (X0909, DakoCytomation, Glostrup, Denmark) for $10 \mathrm{~min}$.

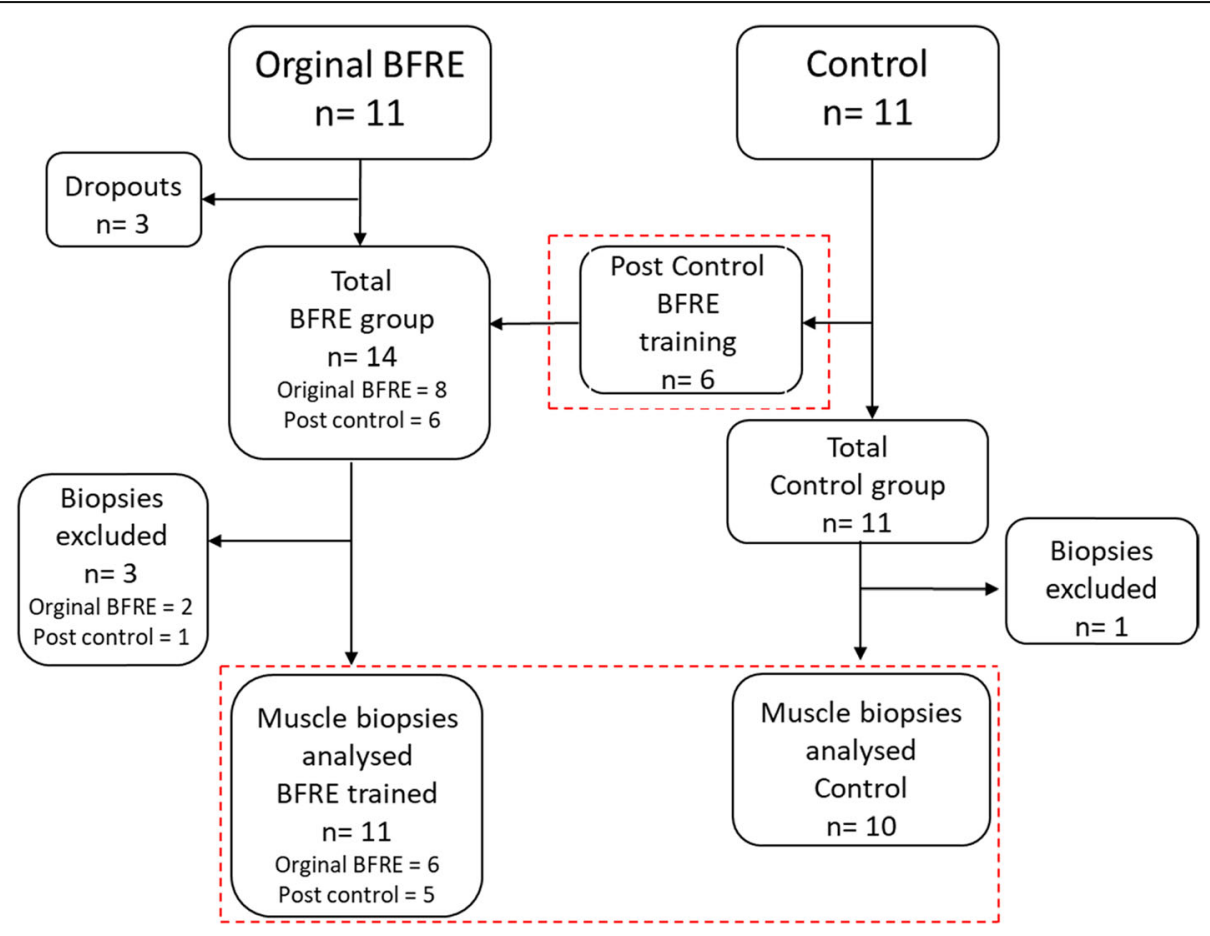

Fig. 1 Flowchart of included patients (original BFRE and control). Post control, patients from the control who underwent the BFRE training intervention after the 12-week control period 
Primary antibodies were incubated overnight at $4{ }^{\circ} \mathrm{C}$. Standard secondary antibodies were incubated for 60 min at room temperature, whereas the $\mathrm{AB} 488$ Vector Mouse enhancer kit was used according to manufacturer's instructions (Vector, Burlingame, USA) (see Table 2 for a detailed listing of the antibodies used). Antibody incubation was followed by a wash step procedure by using PBS, and every antibody cycle (primary and secondary) was followed by wash step and protein blocking.

After completion of the last antibody cycle, DAPI (62248, Thermo Fisher, Rockford, USA) was placed on the sections and washed off after $5 \mathrm{~s}$. Sections were mounted with Vector AQ mounting medium (H-5501, Vector, Burlingame, USA).

Stainings were visualised using a light microscope (Carl Zeiss Axio Imager M1, Germany) with a highresolution AxioCam (Carl Zeiss, Germany) (see Fig. 2 for representative immunohistochemical stainings).

\section{Data processing}

All images were analysed using Visiopharm image analysis software (Visiopharm, Hoersholm, Denmark). Images were analysed using the following three-step protocol:

1) Identify and mark the area containing longitudinal and cross-sectional muscle fibres.

2) Identify immunological markers for T cells, NK's, M1, and M2 macrophages, and write the script that enables Visiopharm to correctly identify and quantify (i.e. number of immune-positive cells) the respective antibody markers. This methodology was verified by manual counting performed by an experienced researcher.

3) Normalise the number of positive cells to the analysed area (counts $/ \mathrm{mm}^{2}$ ).

4) Across the BFRE and CON biopsies, an average area of $3.81 \pm 2.01$ and $3.07 \pm 1.76 \mathrm{~mm}^{2}$ was analysed, respectively.
All data analysis was performed by an investigator blinded with respect to patient ID, group allocation and time-point.

\section{Statistical analysis}

A linear mixed model was used to evaluate if there was a within- and between-group change in the selected immune response markers. The model was adjusted for age, months since diagnosis and whether on immunosuppressive medication or not.

Statistical significance level was set at $p=0.05$. All investigated variables are presented as mean with $95 \%$ confidence intervals (CI) unless otherwise stated. All statistical analyses were performed using Stata (version 14.2; StataCorp, College Station, TX, USA).

In addition, a qualitative analysis of the images was performed for all patients listed in Table 1 . The aim of this analysis was to examine pre-to-post changes in the pattern of grouping of specific immune cell types.

\section{Results \\ Adaptive immune response \\ Quantitative assessment}

The overall number of $\mathrm{CD}^{+} \mathrm{T}$ cells, $\mathrm{CD}^{+} / \mathrm{CD}^{+}$ cytotoxic $\mathrm{T}$ cells and $\mathrm{CD}^{+} / \mathrm{CD} 28^{\text {null }}$ cytotoxic subpopulation did not change following the 12-week intervention period in patients allocated to BFRE training or in CON (Fig. 3a, b). In contrast, CD28 $8^{\text {null }}$ expressing $\mathrm{T}$ cells $\left(\mathrm{CD}^{+} / \mathrm{CD} 244^{+}\right)$decreased from $24.2(12.4,36.0)$ cells $/ \mathrm{mm}^{2}$ to $10.6(-1.1,22.4)$ cells/ $\mathrm{mm}^{2}(p=0.032)$ in $\mathrm{CON}$, while remaining unchanged in BFRE (Fig. 3c), resulting in a between-group difference $(p=0.009)$.

No changes in $\mathrm{T}_{\text {reg }}\left(\mathrm{FOXP}^{+}\right)$expression were noted with BFRE training or in CON (Fig. $3 \mathrm{~d}$ ). $\mathrm{T}_{\text {reg }}$ cells expressing CD28 ${ }^{\text {null }}$ averaged $62.6 \%$ and $77.5 \%$ of the total $\mathrm{T}_{\text {reg }}$ cell population in BFRE and CON, respectively. No changes were observed following the period of the intervention.

Table 2 Overview of antibodies and incubation times

\begin{tabular}{|c|c|c|c|c|c|c|}
\hline Antibody & Origin & Target & Company & Catalogue number & Dilution & Incubation \\
\hline$\overline{C D 3}$ & Rabbit & T cells & Dako/Agilent & A0452 & $1: 2000$ & Overnight \\
\hline CD8 & Mouse & T cells and NK & Dako/Agilent & M7103 & 1:100 & Overnight \\
\hline CD68 & Mouse & $\mathrm{CD} 8^{+}$macrophages & DakoCytomation & M0814 & $1: 400$ & Overnight \\
\hline CD206 (MMR) & Goat & CD $206^{+}$macrophages & DakoCytomation & AF2534 & $1: 400$ & Overnight \\
\hline CD244 & Goat & CD28null T cells & R\&D Systems & AF1039 & 1:100 & Overnight \\
\hline DAPI & & DNA & Thermo Fisher & 62248 & 1:10000 & $10 \mathrm{~s}$ \\
\hline FoxP3 & Mouse & Treg cells & Thermo Fisher & $11-4777-82$ & $1: 500$ & Overnight \\
\hline Laminin & Rabbit & Basal membrane & DakoCytomation & Z0097 & $1: 2000$ & Overnight \\
\hline MHC_fast & Mouse & Type 2 fibres & Sigma-Aldrich & M4276 & $1: 1000$ & $30 \mathrm{~min}$ \\
\hline
\end{tabular}



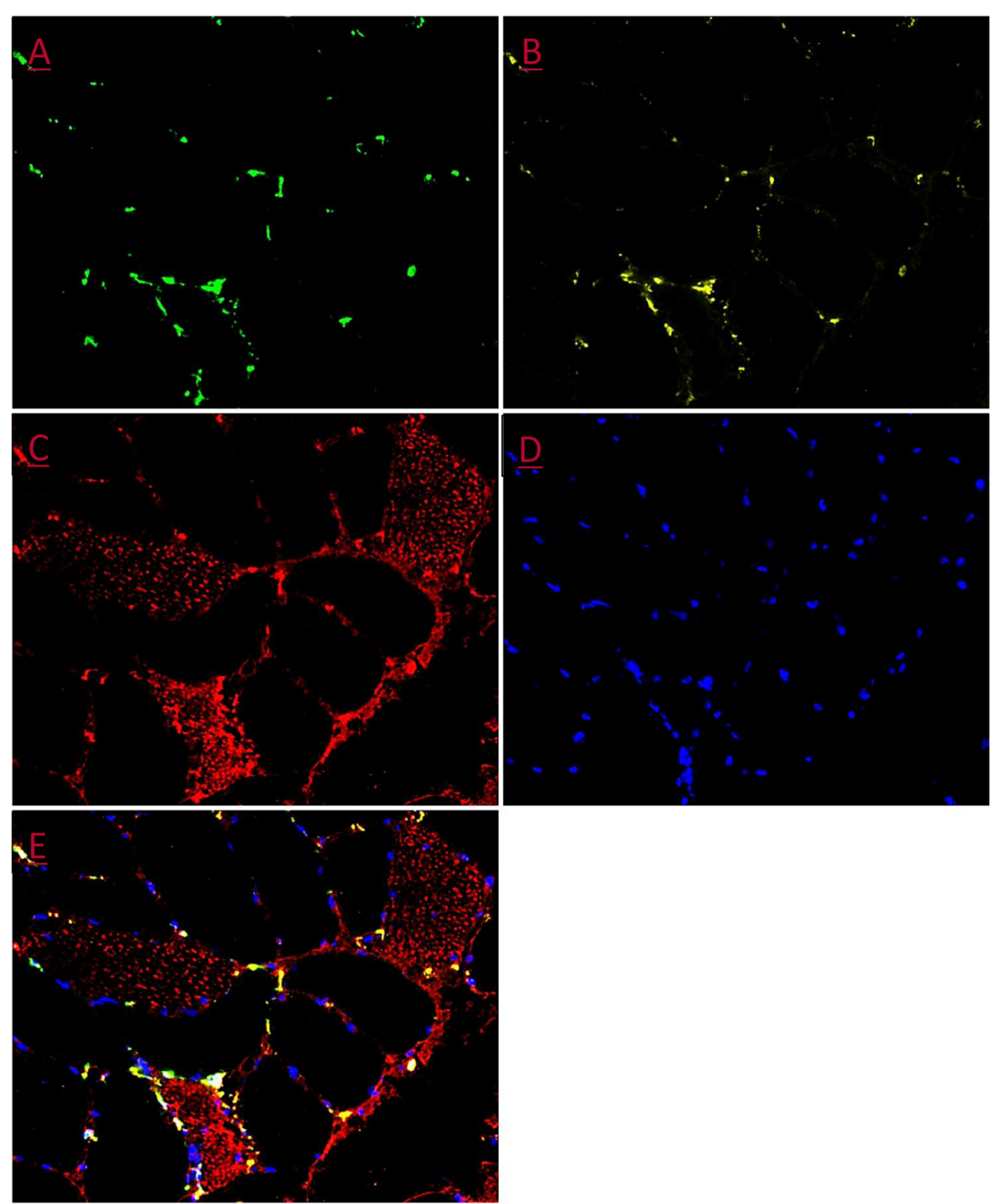

Fig. 2 Representative immunohistochemical staining. a CD-68. b CD-206. c MHC-Fast. d Nuclei/DAPI. e Merged

\section{Qualitative assessments}

No post-intervention changes in the pattern of spatial localisation of $\mathrm{CD}^{+} \mathrm{T}$ cells or $\mathrm{CD}^{+} / \mathrm{CD}^{+}$ cytotoxic $\mathrm{T}$ cells were noted in sIBM patients demonstrating low baseline levels of inflammation. In contrast, patients with high baseline levels of inflammation typically demonstrated an increased frequency of $\mathrm{T}$ cell clusters following BFRE training (Fig. 4a). No changes were observed for $\mathrm{T}_{\text {reg }}$ cells or $\mathrm{CD}^{+} / \mathrm{CD} 28^{\text {null }} \mathrm{T}$ cells in BFRE except in patients with marked groupings of $\mathrm{CD}^{+} \mathrm{T}$ cell infiltration at baseline, in which case clusters of $\mathrm{CD}^{+} \mathrm{T}$ cell infiltration tended to also express CD28 ${ }^{\text {null }}\left(\mathrm{CD} 244^{+}\right)$following BFRE training. No qualitative changes were observed for any $\mathrm{T}$ cell-related immune markers in CON from pre to post.

\section{Innate immune response}

\section{Quantitative assessment}

Pro-inflammatory M1 macrophages $\left(\mathrm{CD}^{+} 8^{+} / \mathrm{CD} 206^{-}\right)$ and anti-inflammatory M2 macrophages $\left(\mathrm{CD}^{+} 8^{+}\right.$ $\mathrm{CD}^{206^{+}}$) remained unchanged following BFRE intervention as well as in CON (Fig. 3e, f).

NK cell subpopulation $\left(\mathrm{CD}^{-} / \mathrm{CD}^{+}\right)$density increased following BFRE training from $5.7(-2.5,14.0)$ to 13.9 $(5.6,22.1)$ cells $/ \mathrm{mm}^{2}(p=0.003)$ while no changes were observed in $\mathrm{CON}(p=0.12)$ (Fig. $3 \mathrm{~g})$, resulting in a between-group difference $(p=0.002)$.

\section{Qualitative assessment}

M2 macrophages $\left(\mathrm{CD}^{+} 8^{+} / \mathrm{CD} 206^{+}\right)$appeared to co-localise more closely to type 2 fibres following the period of BFRE training. Further, several post-intervention biopsies 


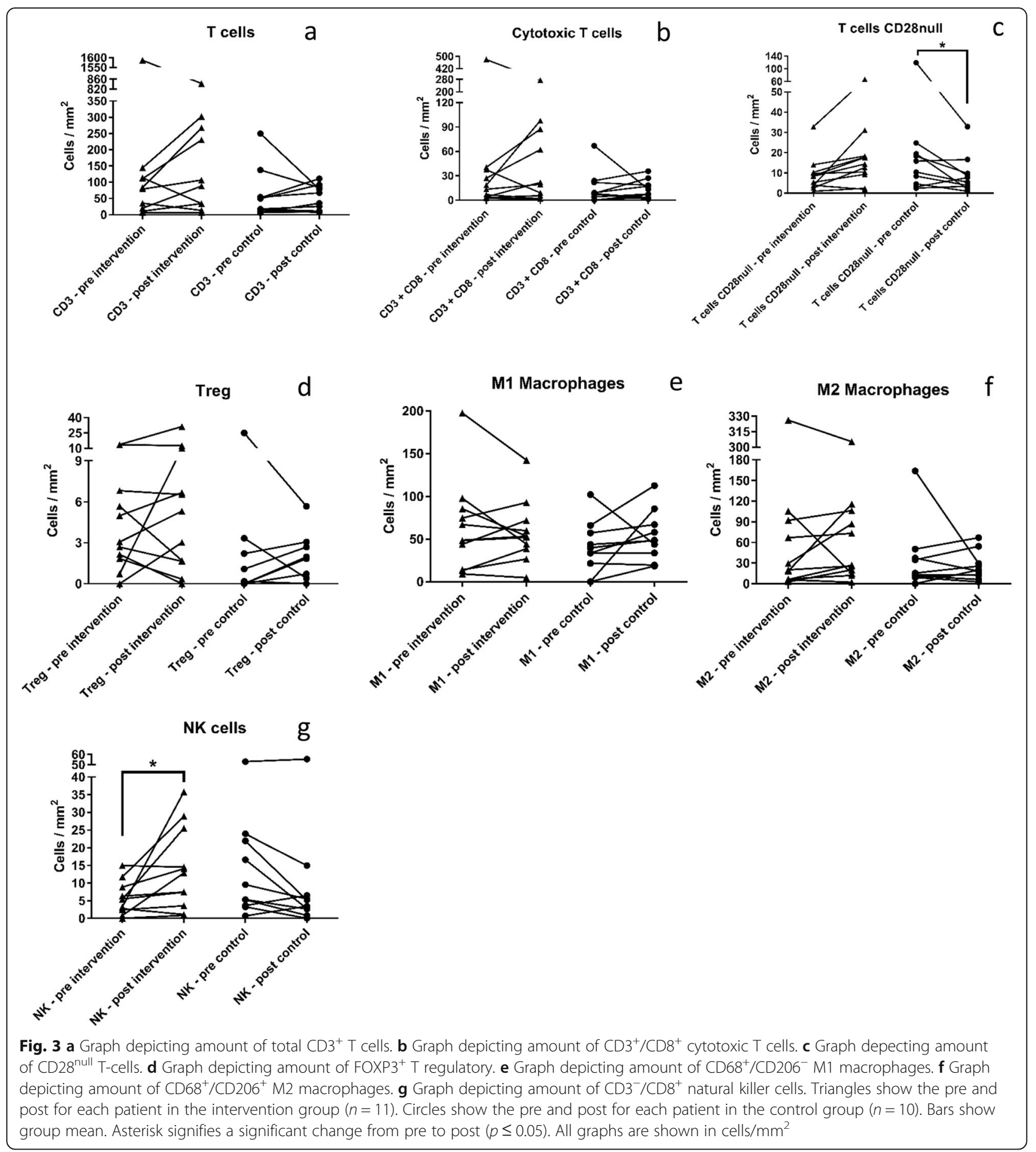

demonstrated signs of clustered macrophage inflammation in the subcellular interstitial space, which was also observed to co-localise more strongly with small-sized type 2 fibres compared to type 1 fibres (Fig. 4b, c).

No change in the localisation pattern of NK cells was observed following BFRE training in sIBM patients with low levels of inflammation and/or few clusters of NK cells at baseline. However, patients with high baseline levels of inflammation and/or high numbers of NK cell clusters typically demonstrated a further increase in NK cell grouping following the period of BFRE training. No qualitative changes were observed in $\mathrm{CON}$ from pre to post.

\section{BFRE intervention-responders vs non-responders}

The present data revealed a large within-group variability in $\mathrm{T}$ cells, macrophages and in the subpopulation of 


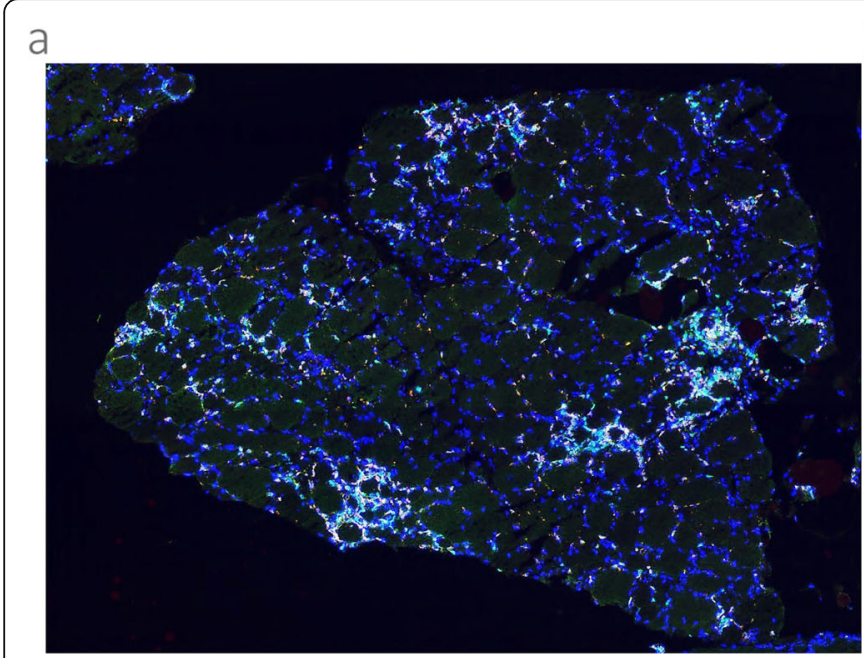

b
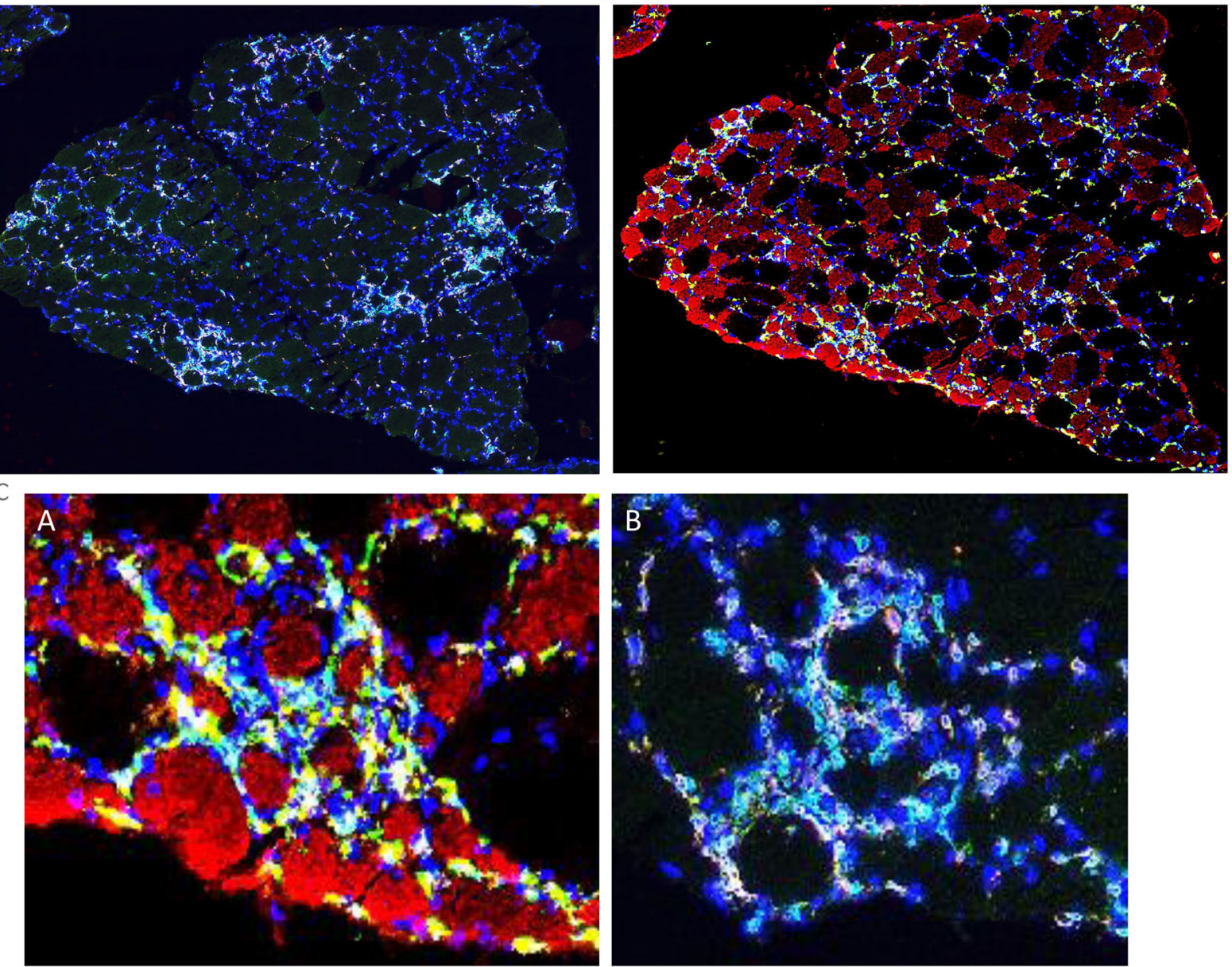

Fig. 4 a Overview of a T cell staining CD-3 (green), CD-8 (red) and nuclei (Blue). See $\mathbf{b}$ for a macrophage staining of the same area. b Overview of a macrophage staining CD-68 (green), CD-206 (yellow), MHC Fast (red) and Nuclei (blue). See a for a T cell staining of the same area. c Close up comparison of the same area showing overlapping macrophage and T cell staining around small-sized type 2 fibres. (A) Macrophage staining, with CD-68 (green), CD-206 (yellow), MHC Fast (red) and Nuclei (blue). (B) T cell staining, with CD-3 (green), CD-8 (red) and Nuclei (blue)

NK cells, which demonstrating at the histopathological level, myositis patients comprise a highly heterogeneous group. A within-group comparison of patients exposed to BFRE training was performed between patients who showed improvements in all functional test parameters (Timed Up and Go, 30-s Chair Rise, 2-min Walking Test-data previously reported [38]) versus patients who demonstrated a decline in performance in at least two out of three functional test parameters (Table 3).

As illustrated in Table 3, patients (FP 22/15) with uniform improvements in functional capacity demonstrated uniform changes in the composition of their inflammatory profile. The only noticeable exception was for M2 macrophage's response, where FP22 showed a minor decrease $(<10 \%)$ following BFRE training. In contrast, patients demonstrating a general decline in functional capacity in response to BFRE intervention (FP 3/14/20) showed a more variable and less uniform pattern of change in inflammatory profile. Specifically, $\mathrm{T}$ cells increased more than $10 \%$ for these patients (FP 3/14/20) while cytotoxic $\mathrm{T}$ cells increased in two out of three patients. Changes in M2 macrophage content exceeded $10 \%$ in two out of the three patients with concurrent decline in functional capacity (FP 3/14/20) (Table 3).

Comparing BFRE-trained responders to nonresponders, a number of notable trends were observed. As an overall pattern, $\mathrm{T}$ cells, cytotoxic $\mathrm{T}$ cells, the cytotoxic subpopulation and M2 macrophages seemed to change reciprocally with changes in functional status, demonstrating decreasing values in those patients who improved their functional capacity, while increasing in patients with a decline in performance. Notably, a majority (4/5) of BFRE trained patients showed $a \geq$ $10 \%$ increase in CD28 $8^{\text {null }} \mathrm{T}$ cells following the period of BFRE training. 
Table 3 Responders vs. non-responders to BFRE training. Responders, patients showing progress in all three tests of functional capacity (FP22, FP15); non-responders, patients with a decline in at least two of the tests of functional capacity (FP3, FP14, FP20). An upregulation (positive response) is defined as a 10\% increase or more. A decline (negative response) is defined as 10\% decrease or more. No change is defined as a change of less than $10 \%$

\begin{tabular}{|c|c|c|c|c|c|c|c|c|c|c|c|c|c|c|c|c|c|c|}
\hline \multirow[t]{2}{*}{ Patient } & \multicolumn{3}{|c|}{$\mathrm{T}$ cells $\left(\mathrm{CD}^{+}\right)$} & \multicolumn{3}{|c|}{$\begin{array}{l}\text { Cytotoxic T cells } \\
\left(\mathrm{CD}^{+}{ }^{+} \mathrm{CD} 8^{+}\right)\end{array}$} & \multicolumn{3}{|c|}{$\begin{array}{l}\text { CD28 }{ }^{\text {null }} T \text { cells } \\
\left(\text { CD3 }^{+} \text {CD244 }\right.\end{array}$} & \multicolumn{3}{|c|}{$\begin{array}{l}\text { Cytotoxic T cell subset } \\
\left(\text { CD8 }^{+} \text {CD } 244^{+}\right) \\
\end{array}$} & \multicolumn{3}{|c|}{$\begin{array}{l}\text { M1 macrophages } \\
\left(\mathrm{CD}^{+} 8^{+} \mathrm{CD} 206^{-}\right)\end{array}$} & \multicolumn{3}{|c|}{$\begin{array}{l}\text { M2 macrophages } \\
\left(\mathrm{CD} 68^{+} \mathrm{CD}^{\left.206^{+}\right)}\right.\end{array}$} \\
\hline & Pre & Post & Change & Pre & Post & Change & Pre & Post & Change & Pre & Post & Change & Pre & Post & Change & Pre & Post & Change \\
\hline FP 22 & 1689 & 841 & $\downarrow$ & 452 & 24 & $\downarrow$ & 10 & 18 & $\uparrow$ & 74 & 67 & $\leftrightarrow$ & 198 & 142 & $\downarrow$ & 326 & 305 & $\leftrightarrow$ \\
\hline FP 15 & 115 & 29 & $\downarrow$ & 31 & 4 & $\downarrow$ & 10 & 10 & $\leftrightarrow$ & 15 & 6 & $\downarrow$ & 98 & 44 & $\downarrow$ & 106 & 15 & $\downarrow$ \\
\hline FP 3 & 103 & 243 & $\uparrow$ & 22 & 60 & $\uparrow$ & 9 & 18 & $\uparrow$ & 14 & 51 & $\uparrow$ & 67 & 60 & $\downarrow$ & 67 & 73 & $\leftrightarrow$ \\
\hline FP 14 & 3 & 4 & $\uparrow$ & 0.4 & 0.0 & $\downarrow$ & 3 & 13 & $\uparrow$ & 6 & 9 & $\uparrow$ & 13 & 39 & $\uparrow$ & 3 & 20 & $\uparrow$ \\
\hline FP 20 & 10 & 29 & $\uparrow$ & 3 & 6 & $\uparrow$ & 16 & 32 & $\uparrow$ & 10 & 11 & $\leftrightarrow$ & 49 & 53 & $\leftrightarrow$ & 6 & 27 & $\uparrow$ \\
\hline
\end{tabular}

\section{Discussion}

The main finding of the present study was that 12 weeks of BFRE training led to an increased number of $\mathrm{CD}^{-} /$ $\mathrm{CD}^{+}$NK cells in sIBM patients, resulting in a betweengroup difference when compared to untrained sIBM controls. In contrast, CON patients (no training) showed a decrease in the number of infiltrating $\mathrm{CD} 28^{\text {null }} \mathrm{T}$ cells $\left(\mathrm{CD}^{+} / \mathrm{CD} 244^{+}\right)$, resulting in a between-group difference. No longitudinal changes in cytotoxic $\mathrm{T}$ cells $\left(\mathrm{CD}^{+} /\right.$ $\left.\mathrm{CD}^{+}\right)$, regulatory $\left(\mathrm{FOXP3}^{+}\right) \mathrm{T}$ cells and $\mathrm{M} 1$ and $\mathrm{M} 2$ macrophage density were observed following BFRE as well as in CON.

Notably however, qualitative analysis indicated that the spatial positioning of M2 macrophages was altered following BFRE training, as manifested by a preferential accumulation of M2 macrophages around small-sized (possibly atrophied) type 2 fibres.

Macrophage and $\mathrm{T}$ cell densities are known to be high in sIBM patients $[1,22]$, which was supported by the present observations. The elevated levels of macrophages and $\mathrm{T}$ cells at baseline may have affected the present BFRE training response, while also contributing to explain the general lack of improvements in physical function in the present group of BFRE-trained sIBM patients [21]. Something which has otherwise been observed to improve following similar type of training in PM and DM patients [20], who demonstrated low levels of macrophages and $\mathrm{T}$ cells, both at baseline and following training intervention $[40,41]$.

\section{Adaptive immune response}

Previous research on immune system function in IIM patients has mainly been focused on $\mathrm{T}$ cells. In the recent years, $\mathrm{CD} 28^{\text {Null }} \mathrm{T}$ cells have become an increasingly important marker for cytotoxicity and indicator of reduced immunological plasticity in IIM patients, as well as being a highly discussed topic in clinical immunology [22-24, 42-44].

High levels of $\mathrm{CD} 28^{\mathrm{Null}} \mathrm{T}$ cells have been associated with elevated cytotoxicity, impaired immune system plasticity and reduced capacity for $\mathrm{T}$ cell proliferation $[25,26,45]$. Interestingly, the present study demonstrated a longitudinal loss of CD28 ${ }^{\text {Null }} \mathrm{T}$ cells in the non-trained $\mathrm{CON}$ group. At first hand, these data would seem to suggest that refraining from exercise-based physical activity might have a positive effect on immune system function in sIBM patients. In disfavour of this notion, however, BFRE training did not lead to any increase (nor decrease) in CD28 $8^{\text {Null }} \mathrm{T}$ cell content in the present group of sIBM patients. While increasing abundance of CD $28^{\text {Null }} \mathrm{T}$ cells have been associated with progressive ageing [46-48] and inflammatory myopathic disease progression [42], no longitudinal changes in cytotoxic $\mathrm{T}$ cell markers $\left(\mathrm{CD}^{+} / \mathrm{CD}^{+}, \mathrm{CD}^{+} / \mathrm{CD} 28^{\text {Null }}\right)$ were observed in the present study. Collectively, these observations suggest BFRE training to not have any major detrimental effect on the immunological muscle milieu in sIBM patients.

Previous studies in healthy adults have reported that physical exercise upregulates $\mathrm{T}_{\text {reg }}$ cells in peripheral blood, acutely following exercise $[49,50]$. Consequently, we initially expected that low-load BFRE training would lead to an upregulated number of $\mathrm{T}_{\text {reg }}$ cells in our group of sIBM patients. However, no change in $\mathrm{T}_{\text {reg }}$ cell content was observed post intervention. This lack of expected change may have been due to the fact that the present sIBM patients demonstrated a high abundance of $\mathrm{CD} 28^{\text {null }} \mathrm{T}$ cells already prior to training, including high levels of $\mathrm{FOXP3}^{+} / \mathrm{CD} 244^{+}\left(\mathrm{T}_{\text {reg }} / \mathrm{CD} 28^{\text {null }}\right)$ cells that are known to be elevated with increasing age and prolonged disease duration in sIBM patients $[25,26,45]$. The population of $\mathrm{CD} 28^{\text {null }} \mathrm{T}$ cells have been shown to be functionally active, long-lived, oligoclonal lymphocytes that lack or have limited proliferative capacity regardless of subtype allocation $[25,26,45]$.

sIBM patients have lower amounts of activated peripheral $\mathrm{T}_{\text {reg }}$ cells compared to age-matched controls [33]. Animal (mice) experiments have demonstrated that a $\mathrm{T}_{\text {reg }}$-deficient muscle milieu (reduced amounts of $\mathrm{T}_{\text {reg }}$ ) combined with aberrant muscle antigen exposure allows 
spontaneous myositis to occur [51]. Further, it has been reported that the functional suppressive effect of $\mathrm{T}_{\text {reg }}$ cells on the proliferation of autologous $\mathrm{T}$ cells is not impaired in sIBM patients compared to healthy agematched controls [33]. Thus, it may be speculated that the global (muscle and circulating) decline in $\mathrm{T}_{\text {reg }}$ cell abundance at least in part accounts for the impaired muscle regeneration/re-building capacity uniformly observed in sIBM patients. Thus, it becomes of interest to investigate if BFRE training intervention in younger and/ or more newly diagnosed sIBM patients will lead to an upregulation in activated and/or non-activated $\mathrm{T}_{\text {reg }}$ cell content. If documented in futures studies, this could indicate an early-phase responsiveness to anabolic exercise that would emphasise the importance of early diagnosis in sIBM patients, which would allow early exercisebased rehabilitation to be initiated.

\section{Innate immune response}

High-frequent (twice daily) BFRE training [16] as well as exercise in general [52] appear to promote an antiinflammatory macrophage response in healthy young adults. In contrast, no quantitative changes in macrophage content were detected following BFRE training in the present group of sIBM patients.

In skeletal muscle tissue, the transition from a M1- to a M2-dominated milieu is considered supportive for muscle regeneration and has been functionally coupled with myogenesis [32]. However, given that our sIBM patients demonstrated an abundance of both M1 and M2 macrophages prior to training, this might have attenuated or blunted the expected training-induced transition from the M1 towards M2 macrophage state. Thus, potentially resulting in an impaired muscle regeneration response when training. Further, the low and invariant numbers of $\mathrm{T}_{\text {reg }}$ cells presently observed could also account for some of the attenuation of the transition of $\mathrm{M} 1$ towards $\mathrm{M} 2$, as $\mathrm{T}_{\text {reg }}$ cells are important for this transition to occur [32, 53].

When comparing the spatial co-grouping of smallsized possibly atrophied type- 2 fibres with extensive macrophage infiltration to the corresponding myocellular regions stained for $\mathrm{T}$ cells and NK cells, a high degree of overlap was noted. Specifically, the grouping of small-sized type 2 myofibres systematically coincided with high levels of macrophage infiltration (both M1 and $\mathrm{M} 2)$, accompanied by high levels of T cells $\left(\mathrm{CD}^{+}\right)$, cytotoxic $\mathrm{T}$ cells $\left(\mathrm{CD}^{+} / \mathrm{CD}^{+}\right)$and the specific NK cell subpopulation $\left(\mathrm{CD}^{-} / \mathrm{CD}^{+}\right)$(Fig. $\left.4 \mathrm{~b}, \mathrm{c}\right)$.

These observations indicate a concerted immune response mainly targeting small-sized type 2 (atrophied) fibres. Macrophages have recently been reported as being able to obtain immunological memory that affects their responsiveness to subsequent acute tissue injury
[54], which may resemble the ongoing conditions in sIBM patients due to their state of chronic inflammation.

The present study revealed a substantial upregulation in the expression of the investigated NK cell subpopulation following the BFRE intervention (Fig. 3c). At first glance, this observation might be interpreted as a contraindication for the use of BFRE in sIBM patients, as NK cells are known to be of cytotoxic nature [55]. However, it remains unclear of which magnitude NK cell upregulation is required for it to become detrimental to sIBM patients. For example, acute exercise in healthy adults leads to acutely upregulated NK cell number and activity, respectively [36, 56]. Further, the level of NK cells appears to be higher in elderly competitive endurance athletes compared to sedentary age-matched controls [57].

sIBM patients are characterised by high levels of inflamed muscle tissue, and therefore, it could be argued that an elevated NK response would be interpreted as a sign of worsening of their disease state. However, all responding and non-responding sIBM patients demonstrated an upregulation in NK cells irrespectively of their performance in the physical function tests (Table 3), indicating that elevated levels of NK cells are likely not detrimental for functional capacity. Therefore, further investigation of NK cell content and their role in muscle homeostasis should be conducted.

\section{Methodological considerations}

In the present study, paired (pre/post intervention) biopsies from 16 sIBM patients were analysed. To our best knowledge, this is the first report on histological changes in the skeletal muscles of sIBM patients undergoing BFRE training.

The present within-subject design (pre vs. post training biopsy comparisons for each individual study participant) reduced the potential influence of large inter-individual variations on the statistical analysis outcome. In support of this approach, a large magnitude of inter-individual heterogeneity was observed in the present histological data, although the corresponding clinical and functional data showed a more homogenous picture of this patient group [38]. This questions (I) whether sIBM patients can be considered a homogeneous subject group and (II) if the temporal development of the disease alters patients' responsiveness to specific types of interventions, such as low-load BFRE training.

Reproducibility is an issue in histopathology in general and has also been dealt with in the case of inflammatory myopathies (mainly IIM) [58], where a broad range of sensitive cellular and histological markers have been suggested by various expert panels. Disagreement on 
both diagnostic criteria and severity of histological changes seem to exist in the literature, yet reproducible data on severity is important, particularly when it comes to studies on effects of intervention. To overcome this problem the present study employed automatized counting of inflammatory cells, to eliminate inter-observer variance. Our setup allowed detection of co-localisation for cell subclassification, but it would be of interest in future analysis to also include data on topographical distribution parameters, muscle damage, regeneration and vascular properties.

A number of potential limitations may be listed for the present study. Due to the rarity of the disease, a relatively low number of sIBM patients were recruited for the study. Further, a substantial amount of heterogeneity was observed in terms of age, disease duration and medical treatment history [38], which likely explain the corresponding heterogeneity in histopathology among the present group of sIBM patients. Further, no healthy agematched individuals were included, since the overall objective was to investigate the effect of BFRE training on immune system function in sIBM patients. Consequently, it was not possible to adjust the present data for the natural time course of age-related changes. Finally, one patient dropped out of the study due to severe fatigue.

\section{Conclusion}

Blood-flow restricted muscle exercise (BFRE) represents a novel approach in the treatment and/or rehabilitation of sIBM patients. The findings from this study suggest that BFRE training is a feasible and tolerable training regime for sIBM patients, since no detrimental or adverse effects on immune system function could be noted following a 12-week training intervention. Further research into the design of specific BFRE training protocols for sIBM patients is needed. In addition, research efforts into the effect of BFRE training on regenerative myocellular markers including stem cell (satellite cell) proliferation and capillary neoformation also seem warranted to gain a deeper understanding of the potential benefits of BFRE intervention in this frail patient population.

\footnotetext{
Abbreviations

BFRE: Blood flow restriction exercise; CON: Control group/non-exercising control; DM: Dermatomyositis; IIM: Idiopathic inflammatory myopathy; M1: Pro-inflammatory macrophage; M2: Anti-inflammatory macrophage; NK: Natural killer; PBS: Phosphate-buffered saline; PM: Polymyositis; sIBM: Sporadic inclusion body myositis
}

\section{Acknowledgements}

The authors would like to thank Dorte Mengers Flindt for handling the immunohistochemistry and laboratory procedures and Professor Ingrid Lundberg from Karolinska Institute in Stockholm for her valuable input on interpretation of data.

\section{Authors' contributions}

$\mathrm{KYJ}$ and $\mathrm{MJ}$ were responsible for designing the framework for the biopsy analyses. Further, KYJ and MJ acquired the data, conducted the qualitative analysis of the data, interpreted the data and wrote the draft of the article. HDS made contributions to designing the framework for the biopsy analyses. PA made contributions to the article draft. JN contributed with interpretation of the analysed data. ANJ laid the foundations for the conception and design of the original randomised controlled trial. EB provided the statistical knowledge, conducted the multilevel analysis and interpreted the findings. RDB handled the biopsy sampling. SR analysed biopsy material for the macrophage content. LPD and UF were driving forces in conceptualising the randomised controlled trial. Further, they were main revisers of the article. All authors assisted with the revisions of the article and approved the final version.

\section{Funding}

This work was funded by The Region of Southern Denmark [2012 j.nr. 12/ 7763], The Danish Rheumatism Association [R108-A2413] and The A.P. Møller Foundation [SE no. 2928 3958].

\section{Availability of data and materials}

Data is not available due to current GDPR regulations.

\section{Ethics approval and consent to participate}

This study is approved by the Ethics Committee of The Region of Southern Denmark (S-20120166) and adhered to the Helsinki declaration II.

Furthermore, the study was registered at www.clinicaltrials.gov

(NCT02317094) and at The Danish Data Protection Agency (14/32001).

Informed consent (verbally and written) was collected from all patients prior to participation in the study according to Danish law.

\section{Consent for publication}

All patients gave informed consent (verbally and written) for publication.

\section{Competing interests}

The authors declare that they have no competing interests.

\section{Author details}

${ }^{1}$ Department of Sports Science and Clinical Biomechanics, SDU Muscle Research Cluster (SMRC), University of Southern Denmark, Odense, Denmark. ${ }^{2}$ Department of Rheumatology, Odense University Hospital, Odense, Denmark. ${ }^{3}$ Department of Pathology, Odense University Hospital, Odense, Denmark. ${ }^{4}$ Department of Clinical Research, University of Southern Denmark, Odense, Denmark. ${ }^{5}$ Department of Orthopaedics and Traumatology, Copenhagen University Hospital, Rigshospitalet, Copenhagen, Denmark. ${ }^{6}$ Center for Rheumatology and Spine Diseases, Copenhagen University Hospital, Rigshospitalet, Copenhagen, Denmark. ${ }^{7}$ Department of Sport Science and Clinical Biomechanics, Research Unit of Clinical Biomechanics, University of Southern Denmark, Odense, Denmark.

Received: 2 June 2019 Accepted: 21 October 2019

Published online: 18 December 2019

\section{References}

1. Greenberg SA. Inclusion body myositis: clinical features and pathogenesis. Nat Rev Rheumatol. 2019;15(5):257-72.

2. Yunis EJ, Samaha FJ. Inclusion body myositis. Lab Invest. 1971;25(3):240-8.

3. Griggs RC, Askanas V, DiMauro S, Engel A, Karpati G, Mendell JR, et al. Inclusion body myositis and myopathies. Ann Neurol. 1995;38(5):705-13.

4. Karpati G, O'Ferrall EK. Sporadic inclusion body myositis: pathogenic considerations. Ann Neurol. 2009;65(1):7-11.

5. Askanas V, Engel WK, Nogalska A. Pathogenic considerations in sporadic inclusion-body myositis, a degenerative muscle disease associated with aging and abnormalities of myoproteostasis. J Neuropathol Exp Neurol. 2012;71(8):680-93

6. Cox FM, Titulaer MJ, Sont JK, Wintzen AR, Verschuuren JJ, Badrising UA. A 12-year follow-up in sporadic inclusion body myositis: an end stage with major disabilities. Brain. 2011;134(Pt 11):3167-75.

7. Hogrel JY, Allenbach Y, Canal A, Leroux G, Ollivier G, Mariampillai K, et al. Four-year longitudinal study of clinical and functional endpoints in sporadic 
inclusion body myositis: implications for therapeutic trials. Neuromuscular Disord. 2014;24(7):604-10.

8. Skelton DA, Greig CA, Davies JM, Young A. Strength, power and related functional ability of healthy people aged 65-89 years. Age Ageing. 1994; 23(5):371-7.

9. Pearson SJ, Young A, Macaluso A, Devito G, Nimmo MA, Cobbold M, et al. Muscle function in elite master weightlifters. Med Sci Sports Exerc. 2002; 34(7):1199-206.

10. Askanas V, Engel WK. Inclusion-body myositis: muscle-fiber molecular pathology and possible pathogenic significance of its similarity to Alzheimer's and Parkinson's disease brains. Acta Neuropathol. 2008;1 16(6):583-95.

11. Lundberg IE, Nader GA. Molecular effects of exercise in patients with inflammatory rheumatic disease. Nat Clin Pract Rheumatol. 2008;4(11): 597-604.

12. Nader GA, Lundberg IE. Exercise as an anti-inflammatory intervention to combat inflammatory diseases of muscle. Curr Opin Rheumatol. 2009;21(6): 599-603.

13. Alexanderson H. Exercise in myositis. Curr Treat Options Rheumatol. 2018; 4(4):289-98.

14. Benatti FB, Pedersen BK. Exercise as an anti-inflammatory therapy for rheumatic diseases-myokine regulation. Nat Rev Rheumatol. 2015;11(2): 86-97.

15. Dorneles GP, Colato AS, Galvao SL, Ramis TR, Ribeiro JL, Romao PR, et al. Acute response of peripheral CCr5 chemoreceptor and NK cells in individuals submitted to a single session of low-intensity strength exercise with blood flow restriction. Clin Physiol Funct Imaging. 2016;36(4):311-7.

16. Nielsen $\mathrm{L}$, Aagaard $P$, Prokhorova TA, Nygaard $T$, Bech RD, Suetta $C$, et al. Blood flow restricted training leads to myocellular macrophage infiltration and upregulation of heat shock proteins, but no apparent muscle damage. J Physiol. 2017;595(14):4857-73.

17. Hughes L, Paton B, Rosenblatt B, Gissane C, Patterson SD. Blood flow restriction training in clinical musculoskeletal rehabilitation: a systematic review and meta-analysis. Br J Sports Med. 2017;51(13):1003-11.

18. Gualano B, Neves M Jr, Lima FR, Pinto AL, Laurentino G, Borges C, et al. Resistance training with vascular occlusion in inclusion body myositis: a case study. Med Sci Sports Exerc. 2010:42(2):250-4.

19. Jorgensen AN, Aagaard P, Nielsen JL, Frandsen U, Diederichsen LP. Effects of blood-flow-restricted resistance training on muscle function in a 74-year-old male with sporadic inclusion body myositis: a case report. Clin Physiol Funct Imaging. 2016;36(6):504-9.

20. Mattar MA, Gualano B, Perandini LA, Shinjo SK, Lima FR, Sa-Pinto AL, et al. Safety and possible effects of low-intensity resistance training associated with partial blood flow restriction in polymyositis and dermatomyositis. Arthritis Re Ther. 2014;16(5):473.

21. Jorgensen AN, Aagaard P, Frandsen U, Boyle E, Diederichsen LP. Bloodflow restricted resistance training in patients with sporadic inclusion body myositis: a randomized controlled trial. Scand J Rheumatol. 2018, 47(5):400-9.

22. Pandya JM, Fasth $A E$, Zong $M$, Arnardottir $S$, Dani $L$, Lindroos $E$, et al. Expanded $T$ cell receptor Vbeta-restricted $T$ cells from patients with sporadic inclusion body myositis are proinflammatory and cytotoxic CD28null T cells. Arthritis Rheum. 2010;62(11):3457-66.

23. Pandya JM, Loell I, Hossain MS, Zong M, Alexanderson H, Raghavan S, et al. Effects of conventional immunosuppressive treatment on CD244+ (CD28null) and FOXP3+ T cells in the inflamed muscle of patients with polymyositis and dermatomyositis. Arthritis Res Ther. 2016;18:80

24. Pandya JM, Venalis $P$, Al-Khalili L, Shahadat Hossain M, Stache $V$, Lundberg IE, et al. CD4+ and CD8+ CD28(null) T cells are cytotoxic to autologous muscle cells in patients with polymyositis. Arthritis Rheumatol. 2016;68(8):2016-26.

25. Weng NP, Akbar AN, Goronzy J. CD28(-) T cells: their role in the ageassociated decline of immune function. Trends Immunol. 2009;30(7):306-12.

26. Strioga M, Pasukoniene V, Characiejus D. CD8+ CD28- and CD8+ CD57+ T cells and their role in health and disease. Immunology. 2011;134(1):17-32.

27. Sakaguchi S, Yamaguchi T, Nomura T, Ono M. Regulatory T cells and immune tolerance. Cell. 2008;133(5):775-87.

28. Sakaguchi S, Miyara M, Costantino CM, Hafler DA. FOXP3+ regulatory T cells in the human immune system. Nat Rev Immunol. 2010;10(7):490-500.

29. Waschbisch A, Schwab N, Ruck T, Stenner MP, Wiendl H. FOXP3+ T regulatory cells in idiopathic inflammatory myopathies. J Neuroimmunol. 2010;225(1-2):137-42.
30. Castiglioni A, Corna G, Rigamonti E, Basso V, Vezzoli M, Monno A, et al. FOXP3+ T cells recruited to sites of sterile skeletal muscle injury regulate the fate of satellite cells and guide effective tissue regeneration. PLoS One. 2015;10(6):e0128094.

31. Burzyn D, Benoist $C$, Mathis $D$. Regulatory $T$ cells in nonlymphoid tissues. Nat Immunol. 2013;14(10):1007-13.

32. Tidball JG. Regulation of muscle growth and regeneration by the immune system. Nat Rev Immunol. 2017;17(3):165-78.

33. Allenbach $Y$, Chaara W, Rosenzwajg M, Six A, Prevel N, Mingozzi F, et al. Th1 response and systemic treg deficiency in inclusion body myositis. PLoS One. 2014;9(3):e88788.

34. Tidball JG, Wehling-Henricks M. Macrophages promote muscle membrane repair and muscle fibre growth and regeneration during modified muscle loading in mice in vivo. J Physiol. 2007:578(Pt 1):327-36.

35. Massimino ML, Rapizzi E, Cantini M, Libera LD, Mazzoleni F, Arslan P, et al, $\mathrm{ED} 2+$ macrophages increase selectively myoblast proliferation in muscle cultures. Biochem Biophys Res Commun. 1997;235(3):754-9.

36. Gleeson M, Bishop NC. The T cell and NK cell immune response to exercise. Ann Transplantation. 2005;10(4):43-8.

37. Bigley $A B$, Simpson RJ. NK cells and exercise: implications for cance immunotherapy and survivorship. Discov Med. 2015;19(107):433-45.

38. Jorgensen AN, Aagaard P, Nielsen JL, Christiansen M, Hvid LG, Frandsen U, et al. Physical function and muscle strength in sporadic inclusion body myositis. Muscle Nerve. 2017;56(6):E50-e8.

39. Nielsen JL, Aagaard P, Bech RD, Nygaard T, Hvid LG, Wernbom M, et al. Proliferation of myogenic stem cells in human skeletal muscle in response to low-load resistance training with blood flow restriction. J Physiol. 2012; 590(17):4351-61.

40. Nader GA, Dastmalchi M, Alexanderson H, Grundtman C, Gernapudi R, Esbjornsson $\mathrm{M}$, et al. A longitudinal, integrated, clinical, histological and mRNA profiling study of resistance exercise in myositis. Mol Med. 2010; 16(11-12):455-64

41. Munters LA, Loell I, Ossipova E, Raouf J, Dastmalchi M, Lindroos E, et al. Endurance exercise improves molecular pathways of aerobic metabolism in patients with myositis. Arthritis Rheumatol. 2016;68(7):1738-50.

42. Fasth $A E$, Dastmalchi M, Rahbar A, Salomonsson S, Pandya JM, Lindroos E, et al. T cell infiltrates in the muscles of patients with dermatomyositis and polymyositis are dominated by CD28null T cells. J Immunol. 2009;183(7):4792-9.

43. Loell I, Pandya J, Raghvan S, Zong M, Malmström V, Lundberg IE. Persisting CD28<sup $>$ null $</$ sup $>T$ cells, but not regulatory $T$ cells, in muscle tissue of myositis patients after immunosuppressive therapy. Ann Rheumatic Dis. 2012;71(Suppl 1):A44-A.

44. Pandya J, Venalis $P$, Stache $V$, Al-Khalili L, Malmström $V$, Lundberg I, et al. CD28<sup $>$ null $</$ sup $>T$ cells from myositis patients are cytotoxic to autologous muscle cells in vitro. Ann Rheum Dis. 2012;71(Suppl 1):A44-A5.

45. Vallejo AN. CD28 extinction in human T cells: altered functions and the program of T-cell senescence. Immunol Rev. 2005;205:158-69.

46. Fagnoni FF, Vescovini R, Mazzola M, Bologna G, Nigro E, Lavagetto G, et al. Expansion of cytotoxic CD8+ CD28- T cells in healthy ageing people, including centenarians. Immunology. 1996;88(4):501-7.

47. Effros RB, Boucher N, Porter $V$, Zhu X, Spaulding C, Walford RL, et al. Decline in CD28+ T cells in centenarians and in long-term T cell cultures: a possible cause for both in vivo and in vitro immunosenescence. Exp Gerontol. 1994;29(6):601-9.

48. Chou JP, Effros RB. T cell replicative senescence in human aging. Curr Pharm Des. 2013;19(9):1680-98.

49. Wilson LD, Zaldivar FP, Schwindt CD, Wang-Rodriguez J, Cooper DM. Circulating T-regulatory cells, exercise and the elite adolescent swimmer. Pediatr Exerc Sci. 2009;21(3):305-17.

50. Kruger K, Alack K, Ringseis R, Mink L, Pfeifer E, Schinle M, et al. Apoptosis of T-cell subsets after acute high-intensity interval exercise. Med Sci Sports Exerc. 2016;48(10):2021-9.

51. Young NA, Sharma R, Friedman AK, Kaffenberger BH, Bolon B, Jarjour WN. Aberrant muscle antigen exposure in mice is sufficient to cause myositis in a Treg cell-deficient milieu. Arthritis Rheum. 2013;65(12):3259-70.

52. Petersen AM, Pedersen BK. The anti-inflammatory effect of exercise. J Appl Physiol. 2005;98(4):1154-62.

53. Schiaffino S, Pereira MG, Ciciliot S, Rovere-Querini P. Regulatory $T$ cells and skeletal muscle regeneration. FEBS J. 2017;284(4):517-24.

54. Weavers H, Evans IR, Martin P, Wood W. Corpse engulfment generates a molecular memory that primes the macrophage inflammatory response. Cell. 2016;165(7):1658-71. 
55. Moretta L, Bottino C, Pende D, Vitale M, Mingari MC, Moretta A. Human natural killer cells: molecular mechanisms controlling NK cell activation and tumor cell lysis. Immunol Lett. 2005;100(1):7-13.

56. Shepard RJ, Shek PN. Impact of physical activity and sport on the immune system. Rev Environ Health. 1996;11(3):133-47.

57. Nieman DC, Henson DA, Gusewitch G, Warren BJ, Dotson RC, Butterworth

$\mathrm{DE}$, et al. Physical activity and immune function in elderly women. Med SCi Sports Exerc. 1993;25(7):823-31.

58. De Bleecker JL, De Paepe B, Aronica E, de Visser M, Amato A, Aronica E, et al. 205th ENMC International Workshop: pathology diagnosis of idiopathic inflammatory myopathies part II 28-30 March 2014, Naarden, The Netherlands. Neuromuscular Disord. 2015;25(3):268-72.

\section{Publisher's Note}

Springer Nature remains neutral with regard to jurisdictional claims in published maps and institutional affiliations.

Ready to submit your research? Choose BMC and benefit from:

- fast, convenient online submission

- thorough peer review by experienced researchers in your field

- rapid publication on acceptance

- support for research data, including large and complex data types

- gold Open Access which fosters wider collaboration and increased citations

- maximum visibility for your research: over $100 \mathrm{M}$ website views per year

At $B M C$, research is always in progress.

Learn more biomedcentral.com/submissions 